\title{
Ибрагимова Р.У.
}

\section{Теоретические и практические проблемы, связанные с процедурой медиации}

Башкирский государственный университет

(Россия, Уфа)

doi: $10.18411 / \mathrm{j}-06-2021-208$

\section{Аннотация}

В данной статье рассматриваются некоторые вопросы, связанные с реализацией и осуществлением процедуры медиации на территории Российской Федерации. Не смотря на то, что институт медиации был введен достаточно недавно, уже сформировалась определенная судебная практика, а также существует ряд практических и теоретических вопросов, которые требуют незамедлительного разрешения как со стороны практикующих юристов, так и со стороны законодателя. Это обусловлено тем, что в настоящее время процедура медиации существует, но применяется довольно редко на практике и в связи с этим услуги медиатора не востребованы и стороны до сих пор продолжают добиваться справедливости в судебных заседаниях и отстаивать свою правоту.

Ключевые слова: гражданский процесс, медиация, медиатор, истец, ответчик, стороны.

\section{Abstract}

This article discusses some issues related to the implementation and implementation of the mediation procedure on the territory of the Russian Federation. Despite the fact that the institution of mediation was introduced quite recently, a certain judicial practice has already been formed, as well as there are a number of practical and theoretical issues that require immediate resolution, both by practicing lawyers and by the legislator, this is due to the fact that currently the mediation procedure exists, but is used quite rarely in practice and in this regard, the services of a mediator are not in demand and the parties still continue to seek justice in court sessions and defend their case.

Keywords: civil procedure, mediation, mediator, plaintiff, defendant, parties.

Для того, чтобы более подробно рассмотреть вопросы связанные с процедурой медиации, с которыми в последствии своей деятельности сталкиваются ученые и практикующие юристы необходимо дать определение, что означает медиация и для чего она необходима.

Медиация - это урегулирование спора между сторонами при помощи привлечения медиатора. Главное преимущество медиации заключается в том, что можно заключить соглашение о том, что спор урегулирован сторонами на любой стадии гражданского судопроизводства, об этом указано в Федеральном законе от 27.07.2010 №193-Ф3 «Об альтернативной процедуре урегулирования споров с участием посредника (процедуре медиации)» [1].

Необходимо отметить, что медиаторами являются лица, которые в совершенстве владеют знаниями о стадиях гражданского судопроизводства, а также имеют довольно большой опыт по разрешению различных споров в праве. Поэтому медиаторами, в основном, становятся судьи, которые вышли на пенсию при достижении пенсионного возраста, а также те, у кого закончился срок действия полномочий.

На первый взгляд кажется, что это очень продуманный и выгодный для сторон институт гражданского процесса, но на практике это не так.

Для этого нами будет рассмотрено несколько часто встречаемых проблем с которыми сталкиваются практикующие юристы при заключении медиативного соглашения. 
Во-первых, стоит отметить, что медиация прописана в гражданском процессуальном кодекс Российской Федерации, а именно в статье 153.5, где указано, что медиация является лишь правом сторон на урегулирование спора [2].

Это означает, что стороны не обязаны обращаться к услугам медиатора и соответственно урегулировать спор в досудебном порядке. На наш взгляд это является основной причиной того, почему медиация не широко распространена в России.

Необходимо ввести законодательное регулирование в процедуру медиации, а именно внести изменение, которое затрагивает обязательное применение процедуры медиации при возникновении гражданско-правовых споров.

Во-вторых, необходимо согласие обеих сторон на проведение процедуры медиации. Данный факт связан с тем, что медиация строиться на принципе добровольности, а не принуждения в связи с этим не одна из сторон не может принуждать другую к заключению медиативного соглашения.

Медиативное соглашение может быть заключено в том случае если у сторон выражена воля и волеизъявление заключить данное соглашение, и они пришли к согласию по урегулированию спора.

Для решения указанной проблемы необходимо внести поправку в процедуру медиации, а именно, чтобы она начиналась с согласия одной стороны.

B-третьих, проблема медиативного соглашения связана на прямую с предметом спора. В частности, истец считает, что он правильно обосновал свои доводы в исковом заявлении и считает, что суд должен встать на его сторону в концертном споре с ответчиком. Ответчик же считает наоборот, что он не в чем не виноват и будет доказывать свою правоту всеми возможными законными способами.

Для решения данной проблемы необходимо медиатору объяснить сторонам, что в случае если они придут к медиативному соглашению, то убытки обоих сторон будут намного меньше, чем те убытки, которые они понесут в случае вынесения решения суда.

Таким образом, мы наблюдаем, как реализуется принцип состязательности сторон в гражданском процессе, но при этом стороны никак не могут прийти к решению спора в досудебном порядке и поэтому обратились за защитой нарушенного права в суд.

Вывод вытекает следующий: если стороны не смогли разрешить спор на стадии досудебного урегулирования, то они не смогут его разрешить и при помощи медиации. Исковое заявление со стороны истца как раз-таки и подается в суд для того, чтобы восторжествовала справедливость, и ответчик был привлечен к юридической ответственности, а также нарушенное право истца было восстановлено.

Четвертая проблема связана с личностью конкретного истца, а также ответчика. Каждая из сторон ищет справедливости в суде, и каждая из сторон желает, чтобы справедливость восторжествовала. И сама проблема связана с тем, что стороны не идут на контакт друг с другом и не желают урегулировать возникший спор в досудебном порядке. Поэтому проще обратиться в суд и предоставить право разрешения спора между сторонами судье, который, в свою очередь, вынесет решение в пользу истца или в пользу ответчика.

Для решение данной проблемы требуется повышение квалификации услуг медиатора, а также его постоянная работа со сторонами для того, чтобы объяснить и рассказать им какие риски несут обе стороны в случае вынесения решения не в их пользу.

Также стоит отметить, что помимо практических проблем, связанных с процедурой медиации существуют также и теоретические.

Первая проблема связана с тем, что в Федеральном законе о медиации. Не определена форма согласия сторон на публичные заявления медиатора по существу спора[3]. 
В ней отсутствуют императивное и состязательное начала, нет подробной регламентации процессуальных действий[4].

При этом одна из основных проблем обязательности, обсуждаемых итальянскими юристами и медиаторами, является платность медиации[5].

Для решения вышеуказанных проблем необходим комплексный подход, а также внесение изменений и дополнений в Федеральный закон о медиации, и помимо этого нужно стремиться усовершенствовать саму процедуру медиации. Возможно, стоит сделать её обязательной стадией гражданского процесса, только в том случае если стороны не смогут прийти к медиативному соглашению, то они уже будут искать справедливость в рамках судебного заседания.

Вместо права сторон стоит их обязать проходить процедуру медиации по урегулированию спора. В таком случае, на наш взгляд, это существенно снизит нагрузку на судебные органы, а также большинство споров можно будет урегулировать в досудебном порядке.

Таким образом, можно сделать вывод о том, что в настоящее время существует целый ряд проблем, как с практической, так и с теоретической точки зрения на то, как реализовывается процедура медиации в России и с какими проблемами сталкиваются практикующие юристы. Без комплексного подхода к данным вопросам проблему с реализацией медиативного соглашения не получится решить.

$$
* * *
$$

1. Федеральный закон от 27.07.2010 №193-Ф3 «Об альтернативной процедуре урегулирования споров с участием посредника (процедуре медиации)»// Собрание законодательства РФ. 27.07.2010. - №31. - ст. 4162.

2. Федеральный закон от 14.11.2002 №138-Ф3 «Гражданский процессуальный кодекс Российской Федерации» // Собрание законодательства РФ. - 14.11.2002. - №46. - ст. 4532.

3. Морозов Н.В. Медиация посредничество: проблемы правового регулирования в Российской Федерации // Право и образование. 2011. № 4. С. 100-106.

4. Табаксюрова А. Проблемы развития медиации в России Сборники конференций НИЦ // Социосфера. 2014. № 57. С. 28-32.

5. Синенко В.С. Проблемы реализации принципа добровольности в процедуре медиации // Научные ведомости Белгородского государственного университета. Серия: Философия. Социология. Право. 2014. № 22 (193). С. 104-108.

\section{Казахецян Г.О., Балашов Е.М. \\ Юридическая сущность соглашения о разделе общего имущества супругов}

Кубанский государственный аграрный университет им. И. Т. Трубилина doi: $10.18411 / \mathrm{lj}-06-2021-209$

(Россия, Краснодар)

\section{Аннотация}

В данной работе проанализирован эффективный и современный способ добровольного урегулирования вопросов имущественного характера. В целях эффективного практического применения соглашения о разделе возникает потребность в более детальном правовом регулировании в данной сфере, в частности, необходимо легально закрепить положения о его заключении, содержании, изменении, расторжении и признании недействительным. Между тем, в настоящее время в доктрине исследованию правовой природы и содержания данного соглашения уделяется явно недостаточное внимание. В свою очередь, тема является актуальной в настоящее время.

Ключевые слова: юридическая сущность, соглашение, раздел общего имущества, семья.

\section{Abstract}

This paper analyzes an effective and modern method of voluntary settlement of property issues. In order to effectively apply the division agreement in practice, there is a need 